\title{
Trends
}

Case Report

\section{Impact of a near-death experience and religious conversion on the mental health of a criminal: case report and literature review}

\author{
Impacto de uma experiência de quase-morte e conversão religiosa sobre a \\ saúde mental de um criminoso: relato de caso e revisão da literatura
}

Camilla C. Braghetta, ${ }^{1}$ Glícia P. Santana, ${ }^{2}$ Quirino Cordeiro, ${ }^{3}$ Sergio P. Rigonatti, ${ }^{4}$ Giancarlo Lucchetti ${ }^{5}$

\begin{abstract}
Objective: Near-death experiences have been defined as profound psychological events that may occur to a person while close to death or in a situation of extreme physical or emotional distress. These experiences seem to have an important effect on the patients' mental health and may occur in several situations despite their cultural and religious beliefs.

Case description: The present case report describes the positive impact of a near-death experience (Greyson scale $>7$ ) followed by religious conversion on the mental health of a former prisoner.

Comments: Investigation of the role of near-death experiences by the scientific community could shed light on the coping mechanisms and moral/ethical transformations that take place in these individuals.
\end{abstract}

Keywords: Near-death experience, religion and medicine, criminality, mental health, social reintegration.

\section{Resumo}

Objetivo: As experiências de quase-morte são definidas como eventos psicológicos profundos, que podem ocorrer quando uma pessoa está em morte iminente ou em situação de intensa crise física ou emocional. Essas experiências parecem ter efeito importante sobre a saúde mental desses pacientes e ocorrem em diversas situações, a despeito de culturas e crenças religiosas. Relato de caso: O presente relato de caso descreve a influência positiva de uma experiência de quase-morte (escala de Greyson $>7$ ) seguida de conversão religiosa sobre a saúde mental de um ex-detento.

Comentário: A investigação do papel de experiências de quase-morte em âmbito científico poderia ajudar a elucidar os mecanismos de coping e transformações éticas e morais que ocorrem nesses indivíduos.

Descritores: Experiências de quase-morte, religião e medicina, criminalidade, saúde mental, reinserção social.

\footnotetext{
${ }^{1}$ Hospital São Paulo, Universidade Federal de São Paulo (UNIFESP), São Paulo, SP, Brazil. Associação Médico-Espírita de São Paulo, São Paulo, SP, Brazil. ${ }^{2}$ Clínica Otossono, Anápolis, GO, Brazil. ${ }^{3}$ Faculdade de Ciências Médicas, Santa Casa de São Paulo, São Paulo, SP, Brazil. Instituto de Psiquiatria, Hospital das Clínicas da Faculdade de Medicina da Universidade de São Paulo (HCFMUSP), São Paulo, SP, Brazil. ${ }^{4}$ Instituto de Psiquiatria, HCFMUSP. Conselho Penitenciário do Estado de São Paulo, São Paulo, SP, Brazil. ${ }^{5}$ Universidade Federal de Juiz de Fora, Juiz de Fora, MG, Brazil. Associação Médico-Espírita de São Paulo, São Paulo, SP, Brazil. Hospital João Evangelista, São Paulo, SP, Brazil.

Financial support: none.

Submitted May 22 2012, accepted for publication Nov 28 2012. No conflicts of interest declared concerning the publication of this article.

Suggested citation: Braghetta CC, Santana GP, Cordeiro Q, Rigonatti SP, Lucchetti G. Impact of a near-death experience and religious conversion on the mental health of a criminal: case report and literature review. Trends Psychiatry Psychother. 2013;35(1):81-4.
} 


\section{Introduction}

Individuals who have come close to death often report having experienced mystical events in which they felt as if they were out of their bodies, with strong interior peace. These events have been referred to as near-death experiences (NDE). ${ }^{1}$

NDEs can be defined as profound psychological events that show a similar pattern of perceptions and can occur when a person is close to death or in a situation of extreme physical or emotional distress. ${ }^{2}$

Several conditions have been proposed to explain these findings, e.g., brain hypoxia, ${ }^{3}$ psychological reaction to approaching death, ${ }^{4}$ or a change in the state of consciousness (transcendence), where identity, cognition, and emotion would function independently of the conscious body. ${ }^{5}$ Similar experiences can be induced by electrical stimulation of the temporal lobe, ${ }^{4}$ during hypercapnia, ${ }^{6}$ brain hypoperfusion, ${ }^{7}$ or as a result of the use of certain substances. ${ }^{5}$

Notwithstanding, it is important to highlight that, differently from induced experiences, NDEs cause significant transformations in the lives of people who experience them. ${ }^{5}$ Some prospective studies have shown major behavioral changes in individuals with previous NDEs, as shown in Table $1.5,8-11$

Despite consistent reports describing behavioral changes associated with NDEs, few studies have investigated these changes or their impact on extreme conditions, as is the case of highly dangerous criminals. The present report describes the case of a former prisoner reporting an NDE followed by religious conversion and the influence of the event on the life and mental health of the individual.

\section{Case report}

Our case was a 45-year old male born in the state of Minas Gerais, southeastern Brazil. He reported having committed his first "cruelty" at 9 years of age, when he put fire to his brother's genitals. After that, he got involved with theft and robbery, became a drug dealer and drug user, and was prostituted. He tried to kill his parents because of disagreements. He was first institutionalized at Fundação CASA (for minors). When he turned 19, he was sentenced to 44 years in prison for four homicides and drug trafficking.

After 3 years in prison, when he was 22, he was attacked by other prisoners for revenge. He was stabbed 14 times. This attack caused diaphragmatic rupture and affected several other organs. He was referred to an emergency unit and submitted to surgery.

Later, the prisoner reported to have had a spiritual experience during surgery, where he saw himself descending into the depths of hell. Then, a "divine hand" removed him from that place and lifted him up into the air. He could see himself lying on the operating table, with several doctors around him. The "hand" carried him further up until reaching a certain height, way above the city. While he was up amid clouds, he reported seeing several lights and "a golden city." He manifested a desire to go there, but a voice told him that "he was not ready because he had a mission to accomplish." Then, the "hand" brought him back to his body. He was later surprised to be alive.

After that experience, he reported to have changed his view of life. He regretted his crimes and became involved with religion and spirituality. He also reported a situation in which a former enemy (a man who had tried to kill him several times) was imprisoned. He offered himself to stay in the same cell as his enemy. Contrary to expectations, he did not attack his enemy.

After 26 years in prison, he was granted conditional release in 2010 . He now lives in the metropolitan region of São Paulo, lives with a partner since January 2011, has four children, and attends a Baptist church. He plans to make progress and build a home where he can live with his family. He believes that his mission is to help the next of kin through his life history. He works as a salesperson and has a monthly income of $\mathrm{R} \$ 500.00$ (approximately US\$333.00; conversion rate at the time:

Table 1 - Prospective studies investigating NDEs

\begin{tabular}{|c|c|c|c|c|c|}
\hline Study & Event & Type of patient & Country & Follow-up & Outcomes assessed \\
\hline Van Lommel et al., $2001^{5}$ & Cardiac arrest & Cardiac patients & The Netherlands & 8 years & $\begin{array}{l}\text { Greater acceptance of others, empathy, } \\
\text { understanding, meaning/ purpose of } \\
\text { life, interest in spirituality }\end{array}$ \\
\hline Parnia et al., $2001^{10}$ & Cardiac arrest & Cardiac patients & United Kingdom & 1 year & $\begin{array}{l}\text { Greater self-awareness, feelings of peace } \\
\text { and harmony, being at a point of no return }\end{array}$ \\
\hline Schwaninger et al., $2002^{9}$ & Cardiac arrest & Cardiac patients & United States & 3 years & $\begin{array}{l}\text { Greater understanding of life, changes in } \\
\text { social habits, religious/spiritual beliefs }\end{array}$ \\
\hline Klemenc-Ketis, $2011^{8}$ & Cardiac arrest & Outpatients & Slovenia & 6 months & $\begin{array}{l}\text { Greater tolerance, greater self-awareness, } \\
\text { meaning of life, sense of nature and justice }\end{array}$ \\
\hline Lai et al., $2007^{11}$ & Different events & Dialytic patients & Taiwan & 6 to 10 years & More motivated and friendly \\
\hline
\end{tabular}


1.50). He mentions that his faith prevents him from returning to crime.

In order to obtain a detailed mental health profile of our case, we asked him to answer some scales. Results are listed below.

- Beck Depression Inventory: 11 ( $\leq 15$, normal or mild depression; 16-20, dysphoria; $\geq 20$, depression). ${ }^{12}$

- Beck Anxiety Inventory: 17 (0-10, minimal anxiety; 11-19, mild; 20-30, moderate; 31-63, severe). ${ }^{12}$

- Duke Religion Index, assessing three dimensions of religiosity: organizational religious activity, non-organizational religious activity, and intrinsic religiosity. Our case attended the church more than once a week, was had daily private religious activities, and scored 15 in the intrinsic religiosity dimension (3, low religiosity, to 15 , high religiosity). ${ }^{13}$

- Quality of Life Scale (SF-12): 51.0 in the physical domain and 60.6 in the mental health domain $(0$, poor quality of life, to 100 , very good quality of life). Our case showed average results for the physical domain and above average for the mental health domain. ${ }^{14}$

- Life Orientation Test: 24 (0, less optimistic expectation, to 24 , more optimistic expectation). ${ }^{15}$

- Spiritual Well-Being Scale: 40 (0-48, higher scores indicate greater spiritual well-being). ${ }^{16}$

- Greyson Scale: 27 (scores above 7 suggestive of NDE). ${ }^{17}$

- General Health Questionnaire (GHQ-12): 2 (0-36, lower scores indicate a better mental state) ${ }^{18}$

- Psychopathy Checklist Revised (PCL-R): 12 ( $\geq 23$, presence of prototypical traits of psychopathy; 12-22, partial personality disorders or mild psychopathy; < 12, normal). ${ }^{19}$

Results revealed good scores in mental health assessments, with symptoms characteristic of mild anxiety. Our patient had an optimistic view of life, showed an important degree of spiritual well-being, and frequently engaged in spiritual activities, as part of his daily life. The score obtained on the psychopathy scale (12) was primarily associated with his past history, which involved juvenile delinquency and conduct disorders during childhood. The scores therefore reflect a partial personality disorder, with less severe alterations and allowing for a higher degree of social integration when compared with subjects identified as psychopaths. ${ }^{19}$

The participant signed an informed consent form and agreed to have his case described and published.

\section{Discussion}

There is much discussion about the impact of spirituality on the lives of human beings ${ }^{20,21}$ and also of the influence of NDE on the mental health of individuals. ${ }^{22}$ Some phenomena, such as the continuation of complex mental functions when the brain is inactive or hypoxic, reveal a possible methodological insufficiency of materialistic science in describing these events, because it is based on a reductionist model of classical physics. Some authors have suggested that one type of research that could contribute to investigate these events is precisely the case report, describing the experience of people while close to death. ${ }^{23}$

Our patient most probably had an NDE, as evidenced by the Greyson scale. ${ }^{17}$ In some individuals, NDEs are interpreted as spiritual or religious events, due to the fact that they report encounters with religious or mystical entities, ${ }^{24}$ as well as a feeling of cosmic unity, time and space transcendence, and persistent secondary positive effects. Usually, a change occurs in the person's values and beliefs, leading to a new view of life, ${ }^{24}$ combined with no fear of death. ${ }^{5}$

In our case, the changes caused by the NDE remained present even after 23 years, including good behavior in prison, greater criticism of acts committed in the past, greater interest in spirituality, and greater involvement in religious activities. Similarly, the patient showed social rehabilitation and reintegration, as well as a desire to help other people through his own experience.

It is important to note that, before the NDE, our patient showed characteristics compatible with a diagnosis of antisocial personality disorder, e.g., being insensitive to other people's feelings, a persistent attitude of irresponsibility and disregard for established norms, and an inability for feeling guilt. ${ }^{25}$ Conversely, after the $\mathrm{NDE}$, he was able to forgive and share a cell with a man who had tried to kill him before. Being obedient to the law helped him get closer to his family and to maintain a stable marital relationship.

Some considerations deserve to be made regarding the limitations of the present study. First and foremost, the Greyson scale was used 23 years after the NDE, which may have led to memory bias. Notwithstanding, recent studies have shown evidence of the stability of scale results even after 20-25 years of the first application. ${ }^{26}$ Second, the fact that our study is a case report prevents our findings from being extrapolated to other people and contexts. Finally, psychopathological analysis only through self-report scales may not be sufficiently reliable to exclude psychiatric conditions.

In sum, our case report shows the positive influence of an NDE followed by religious conversion on the mental 
health of a former prisoner. Our description sheds some light on the discussion and scientific investigation of NDEs, in an attempt to achieve a better understanding of coping mechanisms and changes in ethical and moral conducts among individuals.

\section{References}

1. Greyson B. Implications of near-death experiences for a postmaterialist psychology. Psychol Relig Spiritual. 2010;2:37-45.

2. Greyson B. Near-death experiences. In: Cardeña E, Lynn SJ, Krippner S, editor. Varieties of anomalous experience: examining the scientific evidence. Washington: American Psychological Association; 2000. p. 315-52.

3. Lempert T, Bauer M, Schmidt D. Syncope and near-death experience. Lancet. 1994;344:829-30.

4. Appelby L. Near-death experience: analogous to other stress induced physiological phenomena. Br Med J. 1989;298:976-7.

5. Van Lommel P, van Wees R, Meyers V, Elfferich I. Near-death experience in survivors of cardiac arrest: a prospective study in the Netherlands. Lancet. 2001;358:2039-45.

6. French CC. Near-death experiences in cardiac arrest survivors. Prog Brain Res. 2005;150:351-67.

7. Blackmore SJ, Troscianko TS. The physiology of the tunnel. J Near Death Stud. 1989;8:15-28.

8. Klemenc-Ketis Z. Life changes in patients after out-ofhospital cardiac arrest: the effect of near-death experiences. Int J Behav Med. 2013;20:7-12.

9. Schwaninger J, Eisenberg PR, Schechtman KB, Weiss AN. A prospective analysis of near-death experiences in cardiac arrest patients. J Near Death Stud. 2002;20:215-32.

10. Parnia S, Waller D, Yeates R, Fenwick P. A qualitative and quantitative study of the incidence, features and aetiology of near death experiences in cardiac arrest survivors. Resuscitation. 2001;48:149-56.

11. Lai CF, Kao TW, Wu MS, Chiang SS, Chang CH, Lu CS, et al. Impact of near-death experiences on dialysis patients: a multicenter collaborative study. Am J Kidney Dis. 2007; 50:124-32, 132.e1-2.

12. de Vargas D, Dias AP. Prevalência de depressão em trabalhadores de enfermagem de unidade de terapia intensiva: estudo em hospitais de uma cidade do noroeste do Estado São Paulo. Rev Lat Am Enfermagem. 2011;19:9 telas. http://www. scielo.br/pdf/rlae/v19n5/pt_08.pdf. Accessed Jun 2012.
13. Lucchetti G, Granero Lucchetti AL, Peres MF, Leão FC, MoreiraAlmeida A, Koenig HG. Validation of the Duke Religion Index: DUREL (Portuguese Version). J Relig Health. 2012;51:579-86.

14. Ware JE, Kosinski M, Keller SD. SF-12: How to score the SF12 physical and mental health summary scales. Boston: The Health Institute, New England Medical Center; 1995.

15. Bandeira M, Bekou V, Lott KS, Teixeira MA, Rocha SS. Validação transcultural do teste de orientação da vida (TOV-R). Estud Psicol. 2002;7:251-8.

16. Peterman AH, Fitchett G, Brady MJ, Hernandez L, Cella D. Measuring spiritual well-being in people with cancer: the functional assessment of chronic illness therapy - Spiritual Well-Being Scale (FACIT-Sp). Ann Behav Med. 2002;24:49-58.

17. Greyson B. The Near-Death Experience Scale: construction, reliability, and validity. J Nerv Ment Dis. 1983;171:369-75.

18. Gouveia VV, Chaves SS, Oliveira IC, Dias MR, Gouveia RS, Andrade PR. The use of the GHQ-12 in a general population: a study of its construct validity. Psicol Teor Pesq. 2003;19:241-8.

19. Morana HC. Identificação do ponto de corte para a escala PCR-L (Psychopathy Checklist Revised) para a população brasileira: caracterização de 2 subtipos de personalidade; transtorno global e parcial [dissertação]. São Paulo: Universidade de São Paulo; 2003.

20. Lucchetti G, Lucchetti AG, Badan-Neto AM, Peres PT, Peres MF, Moreira-Almeida A, et al. Religiousness affects mental health, pain and quality of life in older people in an outpatient rehabilitation setting. J Rehabil Med. 2011;43:316-22.

21. Braghetta CC, Lucchetti G, Leão FC, Vallada C, Vallada H, Cordeiro Q. Ethical and legal aspects of religious assistance in psychiatric hospitals. Rev Psiquiatr Clin. 2011;38:189-93.

22. Dell'Olio AJ. Do near-death experiences provide a rational basis for belief in life after death? Sophia. 2010;49:113-28.

23. Stevenson I, Greyson B. Near-death experiences. JAMA. 1979;242:265-7.

24. Greyson B. Near-death experiences and spirituality. Zygon. 2006;41:393-414.

25. American Psychiatric Association. Diagnostic and Statistical Manual of Mental Disorders: DSM-IV-TR Fourth Edition. Washington: American Psychiatric Association; 2000

26. Greyson B. Consistency of near-death experience accounts over two decades: are reports embellished over time? Resuscitation. 2007;73:407-11.

\section{Correspondence}

Camilla C. Braghetta

Rua Napoleão de Barros, 715, Vila Clementino

04024-002 - São Paulo, SP - Brazil

Tel.: +55 11 5576-4990

E-mail: camillacasaletti@hotmail.com 